\title{
Incorporating Aged Martensite Model in Residual Stress Prediction of Ferritic Steels Girth Weld
}

\section{Djarot B. Darmadi}

Senior Researcher Brawijaya University Mechanical Engineering Department Faculty of Engineering Malang 65145 Indonesia
The residual stress was predicted through a model of the multi-pass girth weld joint using Finite Element Method (FEM). Coupled ThermoMetallurgy-Mechanical (TMM) analysis was carried out and the predicted final residual stress was compared with experiment data. To study the role of aged martensite in final residual stress, two models were simulated and discussed: models with and without aged martensite (prime martensite only). Comparing the experiment data, the model with aged martensite has shown closer prediction while the one without the aged martensite has over predicted the residual stress.

Keywords: residual stress, girth weld, finite element method, prime martensite, aged martensite.

\section{INTRODUCTION}

Residual stress has detrimental effects on a welded structure, decreasing the susceptibility to failure. It is found that, in space craft propellant tanks rupture takes place in the vicinity of the weld. The tanks experience thermal and mechanical cycles during service and it was stated the contribution of residual stress to the total stress in such welded structure should be accounted [1].

The stress intensity factor, which describes the stress distribution in the crack tip region, determines the residual strength of structures contained cracks [2]. The cracks may grow as a result of fatigue load [3]. In fatigue load, stress intensity factor threshold $\left(\mathrm{K}_{\mathrm{th}}\right)$ is lower for the element with induced residual stress [4]. In fracture criteria, the residual stress decreases stress intensity factor $\left(\mathrm{K}_{\mathrm{I}}\right)$ or total $\mathrm{J}$ integral for linear elastic mechanics or linear plastic mechanics respectively.

Residual stress drives the failure of creep mechanism. Pipelines mostly collapse under stress corrosion cracking (SCC) mechanism. SCC involves three conditions which enhance each other: stress, corrosive surroundings and the susceptibility of materials to the corrosion. The stress can be the working stress and residual stress. In welding, the residual stress magnitude can be significant, thus taking important role in SCC failure.

To measure the residual stress is often impractical or at least difficult to performe as a result of the handicap to reach the desired position, or the welded structures is too large. Regarding those conditions using the verified numerical method prediction gives a reliable solution [5]. Using the numerical method also needs and gives a deep understanding of the welding process itself, which in this case shows how the residual stresses are developed.

The mostly used numerical method is FEM. The

Received: April 2018, Accepted: May 2019

Correspondence to: Djarot B. Darmadi, Brawijaya

University, Mechanical Engineering Department,

Faculty of Engineering, Malang 65145, Indonesia

E-mail: b_darmadi_djarot@ub.ac.id

doi:10.5937/fmet1904901D

(C) Faculty of Mechanical Engineering, Belgrade. All rights reserved major issue of FEM weld modelling is the accuracy. To insure the accurate model is provided, the FEM model is verified using analytic approach and/or validated using experiment results [6]. In this article, only thermal analysis was evaluated. The heat source was the simplest one: point heat source. Analytic verification is carried out for simple cases, while experiment validation can be applied over complex problems [7]. Once a verified/validated FEM model has been obtained, it can be used as a tool to control and determine the parameters of a welding process in order to obtain appropriate performance of a welded structure [8].

Emulating welding processes using FEM also gives deep understanding of the welding phenomenon itself. Some important next mentioned theories have been obtained from FEM weld modelling. Material thermal properties especially thermal conductivity determines temperature distribution of a welding process, which in turn drives the resulted residual stress [9]. In this article, Thermo-Mechanical analysis was developed. The article underlined the importance of "birth and death" technique, but no Metallurgy consideration was involved.

Study on various welding processes shows that the lower total heat embedded in the welded plate causes lower peak temperature in the region far enough from the weld center line although the temperature in weld center is higher. The lower total heat was found in Laser Beam Welding and the higher was in Gas Tungsten Arc Welding [10]. The role of mechanical properties of welded plate, especially the yield strength in the final residual stress has been studied using FEM model [11]. Since the article discussed the modelling of welding process applied to austenitic stainless steel, the metallurgy analysis was not involved. The Solid State Phase Transformation (SSPT) is known to significantly alter residual stress distribution [12]. In this article, coupled Thermo-Mechanical-Metallurgical (TMM) analysis was applied, but only to prime martensite phase transformation was involved.

FEM simulation can be a complement of welding experiments in providing the necessary data needed to determine WPS [13]. When elements reach their melting 
temperature while welding is applied, they lose their stiffness and remain plastic strains [14]. In this article, a rigorous model of coupled TMM analysis was applied to girth welding process using gas metal arc welding (GMAW). The main concern was how to carefully simulate the melting phenomenon. However, the aged martensite with its hardening effect was not involved in the model.

After the knowledge of a welding process has been put in hand (which may be obtained through FEM) and with the availability of verified FEM model, fewer experiment validation is needed to determine WPS, which leads to cost saving.

In recent years, due to available increasing computer power, FEM became a tool with very good prospect. However, predicting residual stress in a welded structure still remains as a difficult task because of its complexity, even more when metallurgical aspects are involved.

Recently it is recommended to admit residual stress when evaluating the integrity of structures. The standard R6 assessment procedure, for example, suggested to involve residual stress analysis of a welded structure through both modelling and measurements $[15,16]$. Many experiments and residual stress numerical modelling have been carried-out for the past decades, but only a limited number of published papers incorporated phase transformation especially for multipass girth weld joint. On the other hand, the use of high strength ferritic steels is increasing and for the ferritic steels phase transformation should be taken into account to obtain precise results.

In this article three-dimensional coupled ThermoMetallurgy-Mechanical model is employed to predict residual stress of girth weld joint in the X70 (a ferritic steel) pipe lines. Two models are studied: a model that incorporates aged martensite and a model that does not incorporate age martensite considerations. Aged martensite in this article is addressed to a martensite which experiences another martensitic transformation. Experiments are carried out to validate the temperature and residual stress predictions to ensure and evaluate the accuracy of developed model. If the developed model is proved to provide accurate results, it will give better understanding of how residual stress developed in multipass welding while SSPT is involved. Furthermore, the model can be used as an "intellecual control" to determine the optimum parameters in a welding process when applied to martensitic steels. For determining WPS, using this model at least the number of experiments can be significantly reduced, which finally can save he budget.

\section{THE GIRTH WELDING PROCESS}

A specific jig as shown in Figure 1 facilitates a girth weld process of X70 pipe. It is a pair of ferritic steel which has $420 \mathrm{~mm}$ diameter, $8 \mathrm{~mm}$ thickness and 210 lengths. The jig maintains automatic welding process which is controlled by a computer. A Lincoln GMAW machine with STT (Surface Tension Transfer) was used. The welding mode was $5 \mathrm{G}$ vertical down, which provides even and neat weld beads. The $5 \mathrm{G}$ vertical down means each layer is comprised of two runs, which were all started at 12 and ended at 6 o'clock positions in clockwise and counter clockwise senses sequentially. End preparations followed AS 2885.2 with planned past design are also included. First, a machined surface preparation providing a trimmed $60^{\circ}$ edge was made. The manual grinder was used to obtain tidy edges and using a hand file the $1.6 \pm 0.8 \mathrm{~mm}$ land was shaped.

An AMV 4000 device was used to record real time welding current and voltage whilst National Instrument USB 6211 interface facilitated temperature history monitoring. All of them were taken while welding was applied.

The X-ray diffraction observed residual stress on 3 and 9 paths. Those lines are passing all areas which are known in welding (weld metal, boundary zone, Heat Affected Zone - HAZ and unaffected base metal) thus representing the distribution of residual stress in the girth welded pipe. Since those lines are far away from the start and end points, it guarantees the condition is in a quasi steady state.
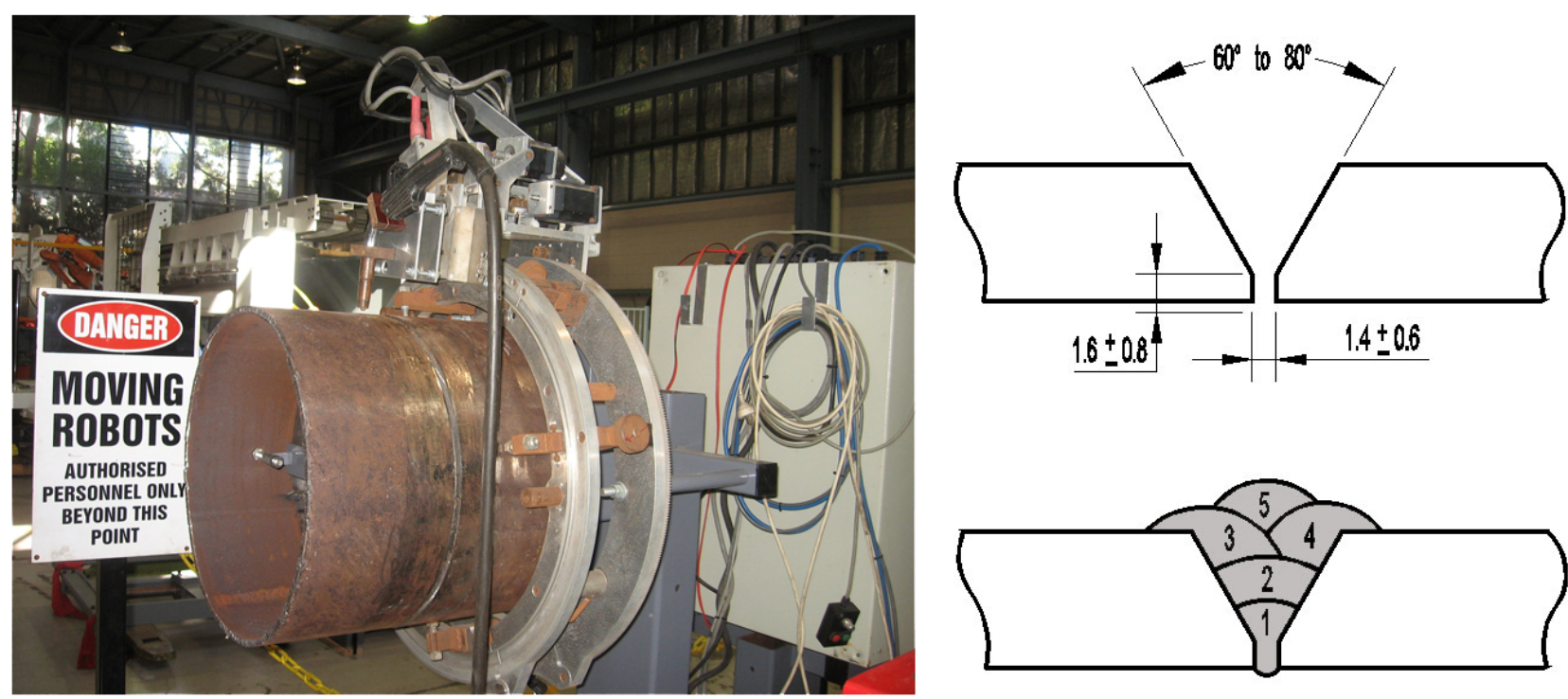

Figure 1. The Girth Welding 


\section{FINITE ELEMENT MODEL}
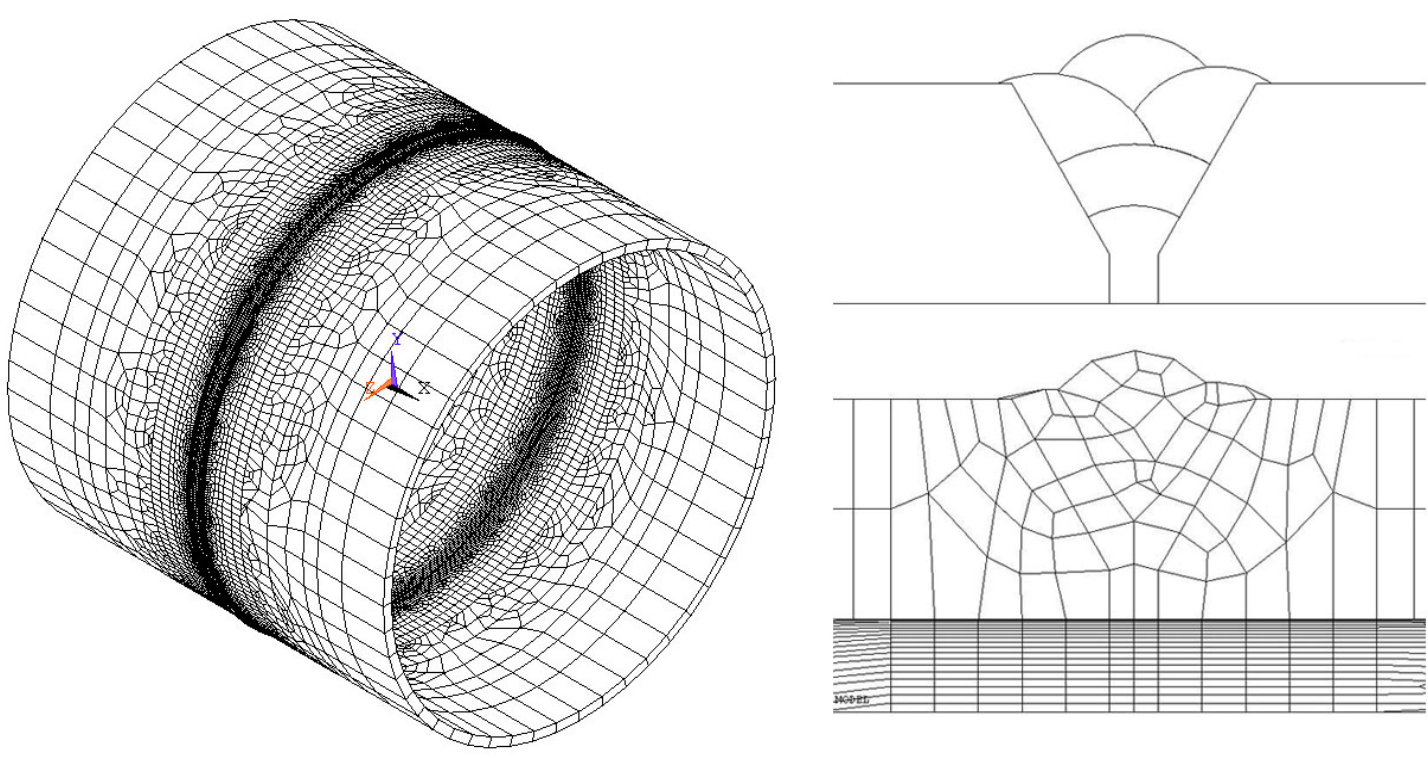

\section{Figure 2. FEM Model of The Girth Weld}

To evaluate the role of age martensite while SSPT takes place, the girth weld was simulated through FEM using ANSYS package program. 78,380 3D-elements of SOLID70 and SOLID45 was used to represent the girth welding. The SOLID70 elements were used in the coupled thermo-metallurgical analysis while in the mechanical analysis the SOLID45 elements were used. Mesh configuration can be seen in Figure 2 (left). Before welding is completed, there is no information about the cross section of weld beads. Furthermore, in real welding the cross section is varied along the weld line. In this paper, the cross section of weld bead was predicted using equation 1. $w f s$ represents wire feed speed and $v$ expresses welding velocity. Following the parameters of the welding process, $v$ is $300 \mathrm{~mm} /$ minute for all passes. $w f s$ is $3 \mathrm{~m} /$ minute for pass 1 and 5 and is $4 \mathrm{~m} /$ minute for pass 2,3 and 4 .

$$
A_{w b}=\frac{\pi d^{2} \cdot w f s}{4 v}
$$

\subsection{Thermal model}

The mixing mode of uniform temperature and volumetric heat loads were applied to emulate heat, which is embedded in welded pipe by welding torch and melted filler metal. The volumetric heat load was distributed following Goldak's model. The Goldak's distribution is expressed mathematically, as shown in Equation 2 which represents heat inserted by welding torch [17]. The uniform temperature load is representing thermal load applying by melted filler metal. A uniform temperature load of $2400^{\circ} \mathrm{C}$ was applied considering that the melting filler metal is superheated and reaches $2400^{\circ} \mathrm{C}[18]$.

$$
\dot{q}_{(x, y, \xi)}^{\prime \prime \prime}=\frac{6 \sqrt{3} \dot{q}}{\pi \sqrt{\pi} r_{x} r_{y} r_{z}} \exp \left(-\frac{3 x^{2}}{r_{x}^{2}}-\frac{3 y^{2}}{r_{y}^{2}}-\frac{3 \xi^{2}}{r_{z}^{2}}\right)
$$

$\dot{q}_{(x, y, \xi)}^{\prime \prime \prime}$ express the rate of volumetric heat load which is applied to an element and in ANSYS known as body heat load. The magnitude of the volumetric heat load depends on the relative position of an element, heat rate and heat source parameters. $\dot{q}$ is the heat rate with the magnitude obtained from measured power of the welding process. The power is the multiplication of welding current and voltage which by AMC 4000 welding monitor. The powers for pass 1 to pass 5 were 1950, 2722, 2500, 2500 and 1950 Volt Ampere respectively. The heat source parameter $r_{x}, r_{y}$ and $r_{z}$ equal $5 \mathrm{~mm}, 2 \mathrm{~mm}$ and $3 \mathrm{~mm}$ respectively $[19,20]$.

Embedded melting filler metal was modelled by growing weld bead. The growing weld bead was simulated using birth and death technique which all beads already modelled but they are deactivated. This grows inactive elements by activating them properly, emulating the embedded melting filler metal. To prevent the heat flow from active elements those deactivated elements should be adiabatically isolated.

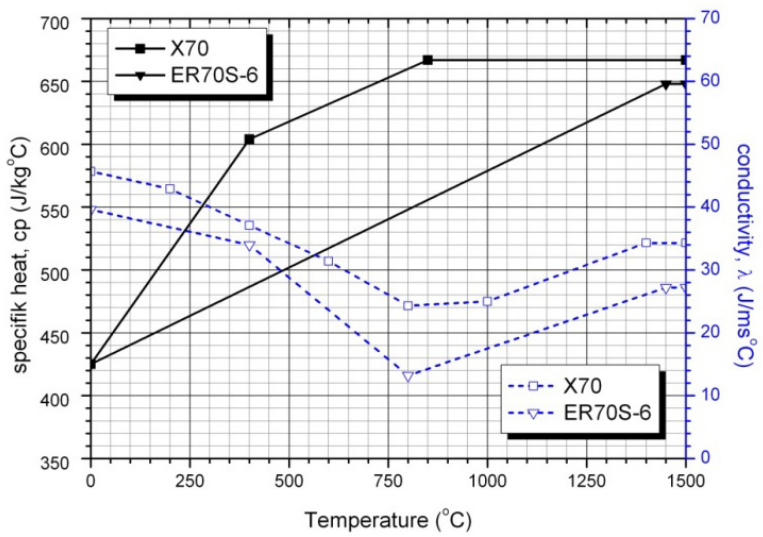

Figure 3. Temperature Dependent Thermal Properties

In thermal model the imperative materials properties are thermal properties which are temperature dependent and shown in Figure 3. The constant value of 7850 $\mathrm{kg} / \mathrm{m}^{3}$ is taken to represent density. 


\subsection{Coupled metallurgical model}

Table 1. Chemical Composition of Weld Metal (Wire) and Base Metal

\begin{tabular}{|c|c|c|c|c|c|c|c|c|}
\hline & $\mathbf{\% C}$ & $\mathbf{\%} \mathbf{M n}$ & $\mathbf{\%} \mathbf{S i}$ & $\mathbf{\% S}$ & $\mathbf{\%} \mathbf{P}$ & $\mathbf{\%} \mathbf{C r}$ & $\mathbf{\%} \mathbf{N i}$ & $\mathbf{\%} \mathbf{M}$ \\
\hline wire & $0.08-0.09$ & $1.42-1.65$ & $0.81-0.87$ & $0.006-0.010$ & $0.004-0.010$ & $0.01-0.05$ & $\leq 0.04$ & $\leq 0.01$ \\
\hline BM & 0.053 & 1.9 & 0.19 & 0.0008 & 0.012 & 0.01 & 0.17 & 0.24 \\
\hline & $\% \mathbf{V}$ & $\% \mathbf{C u}$ & $\% \mathbf{B}$ & $\mathbf{C a}$ & $\mathbf{N}$ & $\mathbf{N b}$ & $\mathbf{T i}$ & $\mathbf{A l}$ \\
\hline wire & $\leq 0.01$ & $0.17-0.22$ & - & - & - & - & - & - \\
\hline BM & 0.044 & 0.01 & $\leq 0.0001$ & 0.0033 & 0.0047 & 0.043 & 0.023 & 0.042 \\
\hline
\end{tabular}

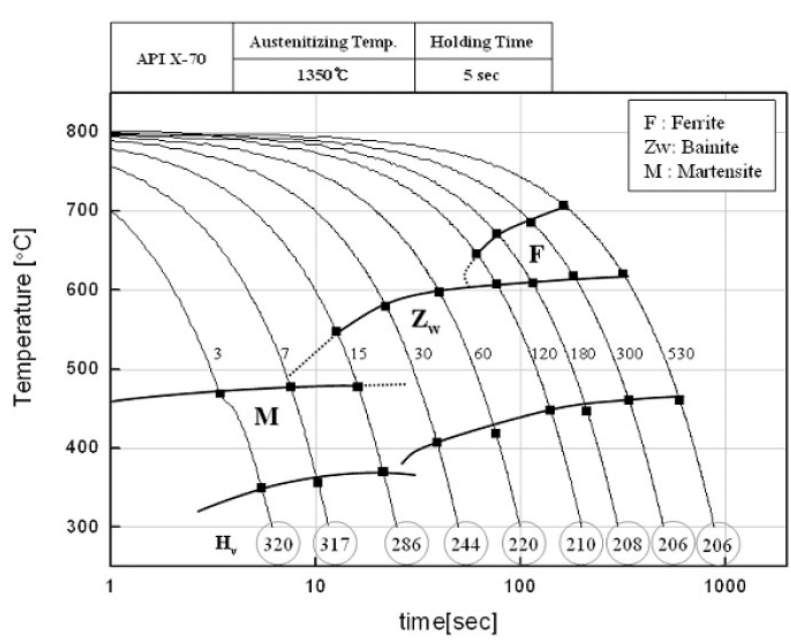

Figure 4. CCT Diagram for High Strength X-70 Steel [19]

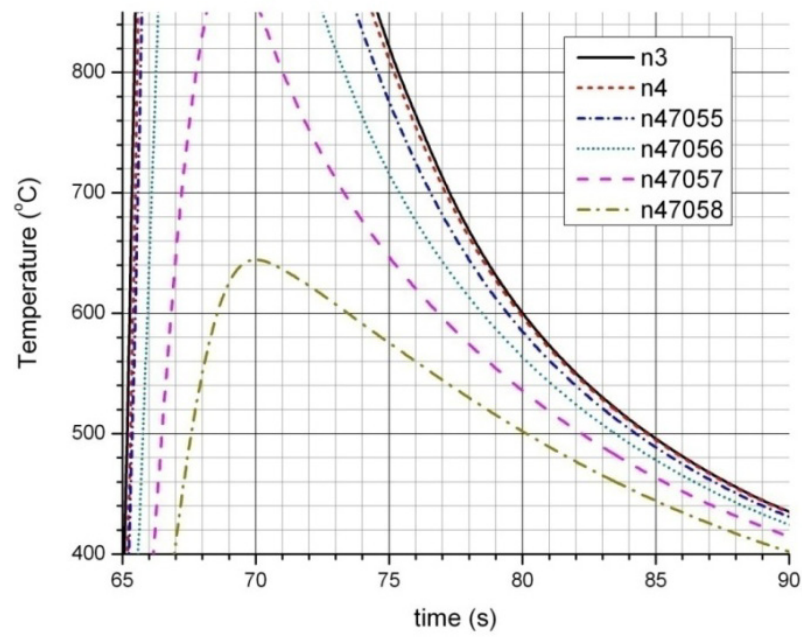

Figure 5. Temperature Histories of Nodes with Varied Transversal Distances

Temperature histories of each element from previous thermal analysis are used to predict the existed SSPT. The first coupled metallurgical model used temperature histories of the model neglecting SSPT and the result is iterated until convergent. Austenite phase transformation exists when elements are heated and the peak temperature is between $\mathrm{Ac}_{1}$ and $\mathrm{Ac}_{2}$, which are $760^{\circ} \mathrm{C}$ and $920^{\circ} \mathrm{C}$ respectively. When these austenite elements cool to room temperature they may be transformed to ferrite/pearlite, bainite or martensite relying on cooling rate. The developed phases can be confronted with the X70's CCT diagram, as shown in Figure 4 based on the cooling rate of the coupled thermo-metallurgical analysis.

In Table 1 is listed the composition of filler and weld metal, which is slightly different with the Ref.
[21]. Indeed, the CCT diagram depends on composition and it was assumed that the difference does not significantly alter the CCT diagram. The temperature of elements, which are suspected to experience austenite transformation was observed. The evaluation of temperature histories when first pass was applied for nodes close to the weld line is shown in Figure 5. Those nodes are at 3 o'clock path on the inner surface of the pipe. In Table 2 the temperature histories are tabulated in a numerical sense. The distance in $\mathrm{mm}$ and peak temperature for each node were shown and the cooling rate is expressed as $t_{8 / 5}$. The $t_{8 / 5}$ describes the time needed to cool from $800^{\circ} \mathrm{C}$ to $500^{\circ} \mathrm{C}$ [22].

Table 2. Cooling Rate of Nodes

\begin{tabular}{|c|c|c|c|}
\hline Nodes & Distance $(\mathrm{mm})$ & Tpeak $\left({ }^{\circ} \mathrm{C}\right)$ & $\mathrm{t} 8 / 5(\mathrm{~s})$ \\
\hline $\mathrm{n} 3$ & 0 & 2400.00 & 9.596 \\
\hline $\mathrm{n} 4$ & 1 & 2400.00 & 9.596 \\
\hline $\mathrm{n} 47055$ & 2.8 & 2070.28 & 10.396 \\
\hline $\mathrm{n} 47056$ & 4.6 & 1287.52 & 11.195 \\
\hline $\mathrm{n} 47057$ & 6.4 & 907.25 & 11.995 \\
\hline $\mathrm{n} 47058$ & 8.2 & 646.28 & $\mathrm{n} / \mathrm{a}$ \\
\hline
\end{tabular}

As can be seen from Table 2 and Figure 5, the cooling rate $(\mathrm{t} 8 / 5)$ for elements which experience austenitic SSPT is less than 13s. From Figure 4 it can be resumed that with this cooling rate only bainite and/or martensite SSPT is developed. The bainite fraction can be estimated using Johnson-Mehl-Avrami-Kolmogrov equation $[14,23]$ as expressed by equation (3).

$$
\mathrm{f}_{\mathrm{b}}=1-\exp \left(-\mathrm{k}(\mathrm{t} 8 / 5)^{\mathrm{n}}\right)
$$

where $k$ and $n$ describe properties, which are material dependence. The $k$ and $n$ for the material under this study can be obtained by confronting equation (3) with CCT diagram for the X-70 base metal (Figure 4). Assuming $95 \%$ bainite fraction is considered as full bainite SSPT which coincides with $\mathrm{t} 8 / 5=100$ s and $5 \%$ bainite fraction is considered as full martensite SSPT, which takes place for $\mathrm{t} 8 / 5=7 \mathrm{~s}$, comes to $k=0.003$ and $n=1.5$. Applying the correction factor 1.053 to obtain $100 \%$ bainite fraction for $\mathrm{t} 8 / 5=100 \mathrm{~s}$, the bainite fraction for the X-70 base metal can be expressed as in equation (4) [14].

$$
\mathrm{f}_{\mathrm{b}}=1.053\left(1-\exp \left(-0.003(\mathrm{t} 8 / 5)^{1.5}\right)\right)
$$

Sequentially after bainite transformation finishes, martensite SSPT takes place. The bainite transformation is finished or martensite SSPT starts at Ms temperature and this martensite SSPT ends at Mf temperature. The martensite fraction may be predicted by modification of Koistenen - Marburger Law [24], which is shown in equation (5). 


$$
\mathrm{f}_{\mathrm{m}}=\left(1-\exp \left(0.011\left(\mathrm{~T}-\mathrm{M}_{\mathrm{s}}\right)\right)\right)
$$

Considering the formed bainite prior to martensite transformation the Koistenen - Marburger Law may be modificated as shown in equation (6).

$$
\begin{aligned}
& \mathrm{f}_{\mathrm{m} / \mathrm{b}-\mathrm{T}}=\left(1-1.053\left(1-\exp \left(-0.003(\mathrm{t} 8 / 5)^{1.5}\right)\right)\right) \\
& \left(1-\exp \left(0.011\left(\mathrm{~T}-\mathrm{M}_{\mathrm{s}}\right)\right)\right)
\end{aligned}
$$

Equation (6) describes martensite fraction at any temperature between $\mathrm{Ms}$ and $\mathrm{Mf}$ and the final portion of martensite can be counted using equation (7).

$$
\mathrm{f}_{\mathrm{m} / \mathrm{b}}=\left(1-1.053\left(1-\exp \left(-0.003(\mathrm{t} 8 / 5)^{1.5}\right)\right)\right)
$$

For varied $t_{8 / 5}$ the final fraction of bainite can be estimated using equation (4) and equation (7) for martensite fraction, which can be presented graphically as shown in Figure 6. Considering Figure 5 and Table 2, the possible composition is shown as shaded area in Figure 6. From Figure 6 it is concieveable to consider that only martensite SSPT takes place, which makes the FEM model much more simpler. Retained austenite, which is typically is below $5 \%$ was also ignored and full martensite SSPT was modeleled.

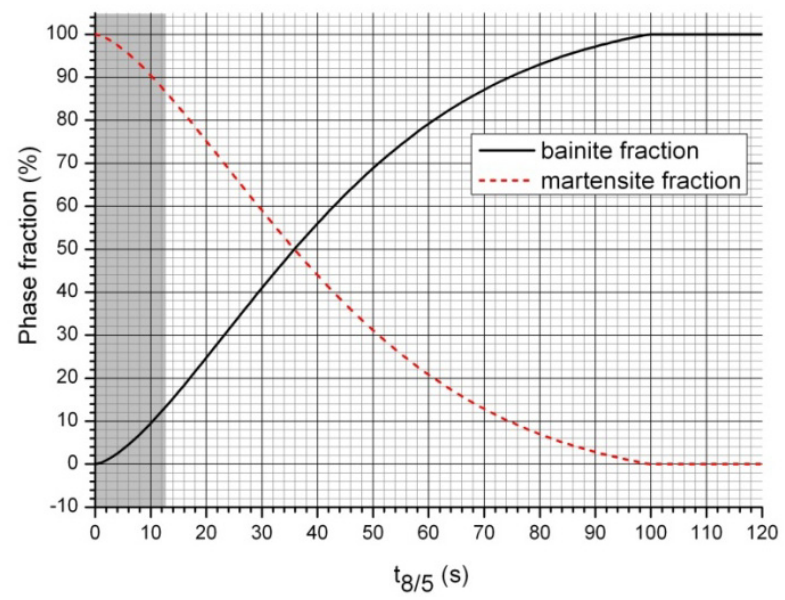

Figure 6. Final Phase as $t_{8 / 5}$ Function

Applying equation (4) for full martensite phase transformation, it needs martensite start temperature, which can be verged by the Andrew formula [25], which is expressed in equation (8). From equation (8) it can be presumed that the $M_{s}$ depends on materials chemical content and by evaluating Table 2, the $M_{s}$ for base and filler metals are $454^{\circ} \mathrm{C}$ and $455^{\circ} \mathrm{C}$, which are almost equal, endorses the previous assumption the CCT diagram for base and filler metals would not be significantly different. This martensite SSPT ends at $M_{f}$, which is considered to be equal to $350^{\circ} \mathrm{C}$ for base and filler metals.

$M_{s}=539-423 \mathrm{C}-30.4 \mathrm{Mn}-12.1 \mathrm{Cr}-17.7 \mathrm{Ni}-7.5 \mathrm{Mo}$

Latent heat is needed when SSPT and solid-liquid phase transformation develop. Latent heat for martensite SSPT can be approached by evaluating enthalpy at certain temperature using Lee formula [26] as shown in equation (9) where $T$ expresses temperature. The latent heat needed for martensite SSPT is enthalpy different for $T=M_{s}$ and $T=M_{f}$ which equals 74.35 and 76.502 $\mathrm{kJ} / \mathrm{kg}$ for base and weld metals respectively. The latent heat for Austenite SSPT is $4200 \mathrm{~J} / \mathrm{mol}$ [27] and considering the composition it is 25.031 and 25.630 $\mathrm{kJ} / \mathrm{kg}$ for base and weld metals respectively. $270 \mathrm{~kJ} / \mathrm{kg}$ latent heat is needed when solid-liquid phase transformation exist, in the range of temperature equal to $1450{ }^{\circ} \mathrm{C}-1500^{\circ} \mathrm{C}$ [28]. Those latent heat and the range of temperature for the phase transformations are tabulated in Table 3.

Table 3. Latent Heat of The Base Metal and Weld Metal

\begin{tabular}{|c|c|c|c|c|}
\hline \multirow{2}{*}{} & \multicolumn{2}{|c|}{ Latent Heat $(\mathrm{kJ} / \mathrm{kg})$} & \multicolumn{2}{c|}{ Temperature range $\left({ }^{\circ} \mathrm{C}\right)$} \\
\cline { 2 - 5 } & Base Mtl & Weld Mtl & Base Mtl & Weld Mtl \\
\hline Martensite & 74.360 & 76.502 & $454-200$ & $455-200$ \\
\hline Austenite & 25.031 & 25.630 & \multicolumn{2}{|c|}{$760-920$} \\
\hline Melting & \multicolumn{2}{|c|}{270} & \multicolumn{2}{c|}{$1450-1500$} \\
\hline
\end{tabular}

$$
H_{M}^{f u n c}(J / m o l)=0.041 T^{2}-0.078 T-5079.047
$$

The developed phase of each element can be predicted based on the peak temperature and the initial phase. In this paper, two scenarios are studied, first FEM model involving tempered martensite and the second FEM model with prime martensite SSPT only. While an element is heated and the peak temperature exceeds $\mathrm{A}_{\mathrm{cl}}$, it experiences austenite transformation. Martensitic transformation takes place on these austenite elements while it cooled down to room temperature. Depending on the phase of the element before it transforms to austenite, tempered martensite SSPT for the first scenario and another prime martensite SSPT for the second scenario will be performed if the element's initial phase is prime martensite. For the austenite elements with initial phase is ferrite/pearlite, only prime martensite SSPT is applied for both scenarios. Considering a latent heat should be spent while SSPT existed, the previous temperature histories for nodes should be re-evaluated. The temperature histories obtained from certain execution, are then confronted with temperature histories from previous execution. In this paper, the evaluation of temperature histories is represented by existing phase and a peak temperature of selected nodes, which are close to the weld line. If these peak temperatures and phases are considered different, it means the results are not in convergence and the thermo-metallurgical analysis is repeated based on the last predicted SSPT. These steps are iterated until the convergence is obtained.

\subsection{Mechanical Model}

Since mechanical results have insignificant effects on the thermal and metallurgy outcomes, the mechanical model was not coupled with both analysis and performed sequentially after coupled thermo-metallurgical analysis has been completed. The non uniform thermal load caused varied thermal expansion which produced geometrical misfit. As a result, the developed stress, usually called thermal stress, eventually exceeds yield stress and causes plastic strain. This plastic deformation, when the welded metal cool down to room temperature remains in elements and causes residual stress.

The stress value strongly depends on mechanical properties, which are temperature dependent. As shown 
in Table 4, mechanical properties of filler metal at room temperature depend on inert gas of GMAW and $90 \% \mathrm{Ar}$ plus $10 \% \mathrm{O}_{2}$ were used. The regression line of Figure 7 is used to represent yield stress at varying temperature. Those $\mathrm{K}_{\mathrm{d}}$ scatter data were collected from various publications [27 - 31]. Using the $\mathrm{K}_{\mathrm{d}}$ regression function and yield strength at room temperature, yield stress at elevated temperature for filler metal can be approached. The temperature dependent on mechanical properties for base and filler metals are shown in Figure 8. A constant value, 0.3, was used for Poisson's ratio whilst thermal expansion are $14 \times 10^{-6}{ }^{\circ} \mathrm{C}^{-1}$ for base metal and $13.24 \mathrm{x}$ $10^{-6}{ }^{\circ} \mathrm{C}^{-1}$ for filler metal.

Table 4. Mechanical Properties of AWS ER706S-6 [23]

\begin{tabular}{|l|c|c|c|}
\hline Inert Gas & $\sigma_{\mathrm{y}}(\mathrm{Mpa})$ & $\sigma_{\mathrm{u}}(\mathrm{MPa})$ & $\varepsilon(\%)$ \\
\hline $100 \% \mathrm{CO}_{2}$ & 440 & 560 & 29 \\
\hline $75 \% \mathrm{Ar}, 25 \% \mathrm{CO}_{2}$ & 460 & 565 & 27 \\
\hline $90 \% \mathrm{Ar}, 10 \% \mathrm{CO}_{2}$ & 470 & 580 & 28 \\
\hline $98 \% \mathrm{Ar}, 2 \% \mathrm{O}_{2}$ & 455 & 565 & 27 \\
\hline
\end{tabular}

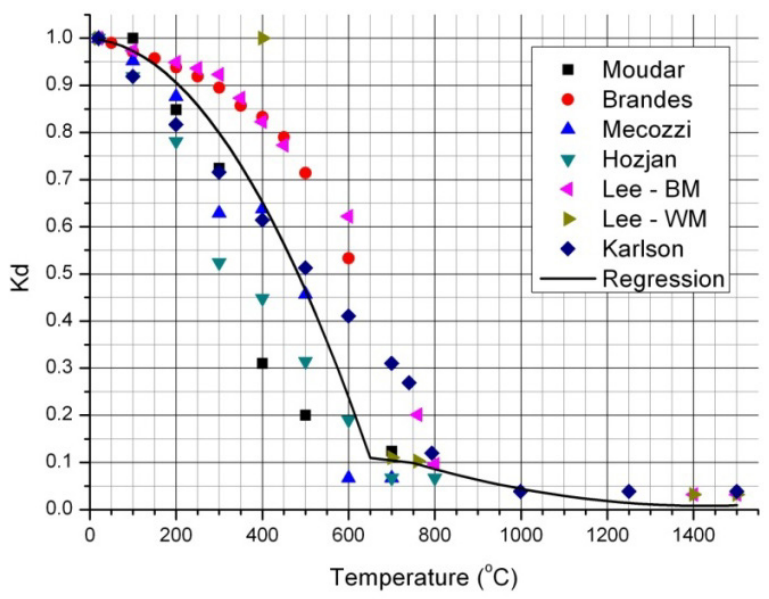

Figure 7. Reduction Factor

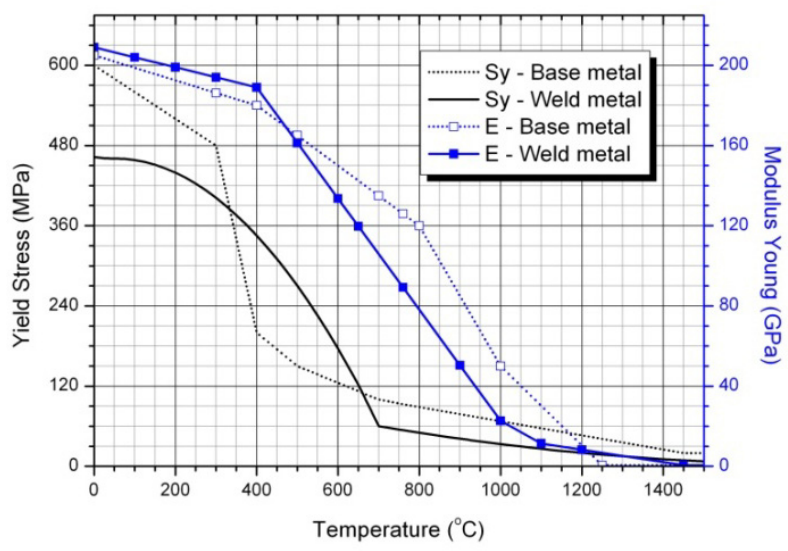

Figure 8. Temperature Dependent Mechanical Properties

\subsection{TMM Analysis}

During the welding process involving SSPT, additional strains are induced due to volumetric change and transformation plasticity along with the thermal strain. Therefore, the total strain $(\varepsilon)$ is the sum of individual components of strains, as shown in equation 10 .

$$
\varepsilon_{\mathrm{tot}}=\varepsilon_{\mathrm{El}}+\varepsilon_{\mathrm{Pl}}+\varepsilon_{\mathrm{T}}+\varepsilon_{\mathrm{Vol}}+\varepsilon^{\mathrm{TrP}}
$$

where $\varepsilon_{E l}, \varepsilon_{P l}, \varepsilon_{T}, \varepsilon_{V o l}$ and $\varepsilon^{T r P}$ are elastic strains, plastic strain, thermal expansion, volumetric change and transformation plasticity of SSPT respectively.

Volumetric change due to SSPT depends on martensite fraction which followed Koestinen - Marburger equation (equation 11) which describes martensite fraction of carbon steels. For a small temperature increment was used the differentiation of the equation (11), which is shown in equation (12).

$$
\begin{aligned}
& \mathrm{f}_{\mathrm{m}}=1-\mathrm{e}^{0.011(\mathrm{~T}-\mathrm{Ms})} \\
& \mathrm{df}_{\mathrm{m}}=-0.011 \mathrm{e}^{0.011(\mathrm{~T}-\mathrm{Ms})} \mathrm{dT}
\end{aligned}
$$

The volumetric change as a result of martensitic SSPT is developed from the equation (12) and expressed mathematically as shown in equation (13).

$$
\Delta \varepsilon_{\mathrm{Vol}}=d f_{m} \times \Delta \varepsilon^{\mathrm{mar}}
$$

where $T$ is instantaneous temperature between $M_{s}$ and $\mathrm{M}_{\mathrm{f}}$ and $\Delta \varepsilon^{\mathrm{mar}}$ equal to $1.5 \times 10^{-5}$ is the SSPT volumetric change of full martensite.

Transformation plasticity was approached using Desalos' normalized function [32] as shown in equation (14) which depends on martensite fraction and working stress. The constant $K$ equalling to $7.25 \mathrm{e}-5\left(\mathrm{MPa}^{-1}\right)$ was taken from previously published paper [33], since it varies from $4.5 \mathrm{e}-5$ to $10 \mathrm{e}-5\left(\mathrm{MPa}^{-1}\right)$.

$$
\varepsilon^{T r P}=K \sigma\left\{f_{m}\left(2-f_{m}\right)\right\}
$$

Using Koestinen-Marburger relation (equation 11) and considering the mid value of $K$, strain due to transformation plasticity in the temperature between $M_{s}$ and $M_{f}$ when martensitic SSPT takes place can be expressed as in equation (15).

$$
\varepsilon^{T r P}=7.25 \times 10^{-5}\left(M P a^{-1}\right) \sigma\left\{1-\exp \left(0.022\left(T-M_{S}\right)\right)\right\}
$$

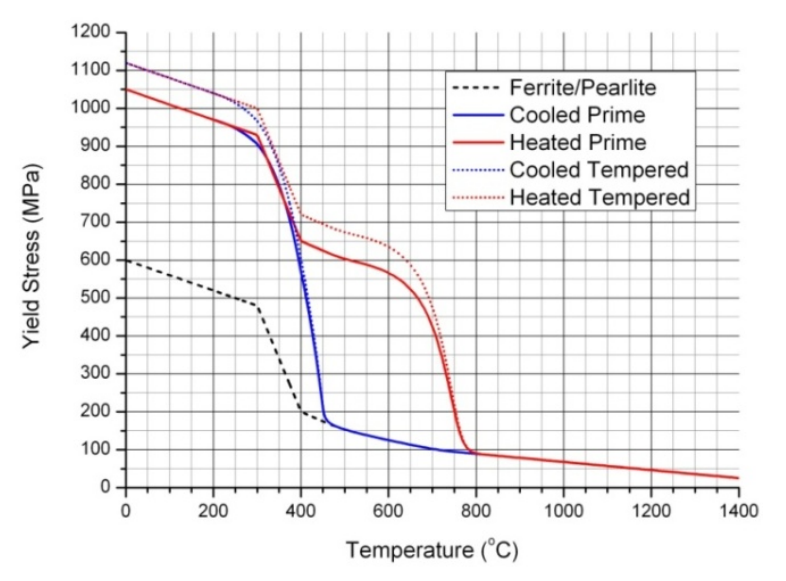

Figure 9. Effects of Prime and Tempered Martensite on The yield stress of base metal

Another phenomenon that should be accommodated is annealing that when the temperature of an element is equal or higher than this annealing temperature the stiffness and remained plastic strains are mitigated. The annealing temperature depends on carbon content, which can be divided into two regimes: hypo and hypereutectoid. The annealing temperature is $50^{\circ} \mathrm{C}$ above $\mathrm{AC}_{3}$ for hypoeutectoid type and for hypereutectoid class 
it is $50^{\circ} \mathrm{C}$ above austenite - cementite line. And for the pipe under this study, which is hypoeutectoid the annealing temperature was considered equal to $970^{\circ} \mathrm{C}$ [13]. The SSPT not only affects strains through volumetric change and transformation plasticity but also alters properties of elements which experience SSPT. Thermal property significantly affected is latent heat which has been shown in Table 3.

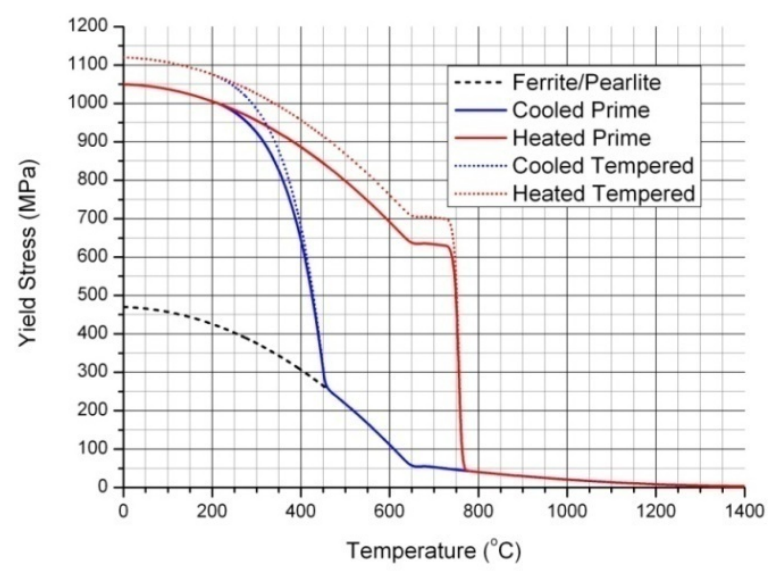

Figure 10. Effects of Prime and Tempered Martensite on The Yield Stress of Weld Metal

Yield stress is the crucial property that significantly influences the stress condition. The yield stress rises while martensite is formed. The increase of the yield stress is determined by the martensite fraction which is evaluated using equation (11). The prime martensite yield stress is $1050 \mathrm{MPa}$ whilst the tempered martensite yield stress is $1120 \mathrm{MPa}$ [34]. The yield stress for the mixed composition was set by weighting the initial yield stress and martensite yield stress according the existing martensite fraction. Figures 9 and 10 describe all possible combined yield stressess as a result of martensite development for both base and weld metals. It should be noted that aged martensite SSPT (dot lines) is only for the first scenario (a model incorporating aged martensite SSPT) and not for the second scenario (a model without aged martensite SSPT).

\section{Results and Discussion}

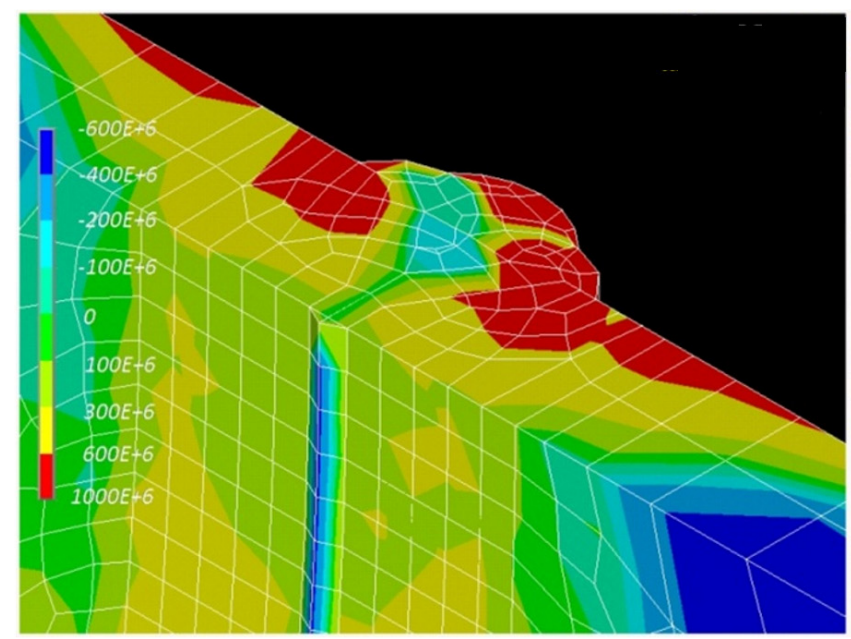

The FEM model was built considering all previously discussed approaches. The final FEM residual stress, then compared to the residual stress measurement. Xray diffraction measured residual stress at surface path at 3 o'clock position, which is considered in quasi steady state. Using two approaches that involve tempered martensite SSPT and a model with prime martensite only, the residual stress in the area of 3 o'clock can be seen in Figure 11. Data retrieved from a path in the outer pipe surface were then compared to experiment results as can be seen in Figure 12. From Figure 11 and 12 it can be seen that a model without tempered martensite SSPT overestimated the resulted residual stress and using the tempered martensite improved the FEM prediction. This result underlined the importance of incorporating tempered martensite SSPT in the girth weld FEM model.

From discussion in section 3 , the eminent difference of tempered martensite is the increased yield stress compared to the prime martensite model as can be seen in Figures 9 and 10 for base metal and weld metal respectively. Or simply, it can be said that increased yield stress of tempered martensite decreases the residual stress in the area close to the weld center. It is quite surprising, since promptly way might consider that the higher yield stress should produce higher residual stress. Explaining this phenomenon may be obtained qualitatively through simple three elasto-plastic bars model [35]. The FEM model of the three elasto-plastic bars will be discussed in the next paragraphs.

Two of the three bars models are simulated to qualitatively represent the girth weld without and with tempered martensite SSPT. First, the middle bar is heated to $1100^{\circ} \mathrm{C}$ and then the thermal load is omitted. In the first model all three bars have yield stress equal to $1000 \mathrm{MPa}$ and in the second the middle bar has elevated yield stress equal to $1100 \mathrm{MPa}$. Stress strain relation for both models are shown in Figure 13. The other typical properties are density $\rho=8000 \mathrm{~kg} / \mathrm{m}^{3}$, thermal conductivity $\lambda=20 \mathrm{~W} / \mathrm{m}^{\circ} \mathrm{C}$, specific heat $\mathrm{c}_{\mathrm{p}}=500$ $\mathrm{J} / \mathrm{kg}^{\circ} \mathrm{C}$, coefficient of thermal expansion $\alpha_{\mathrm{T}}=20 \mathrm{e}-6 /{ }^{\circ} \mathrm{C}$. Using of those values the obtained stresses on the three bars model are shown in Figure 14 and 15.

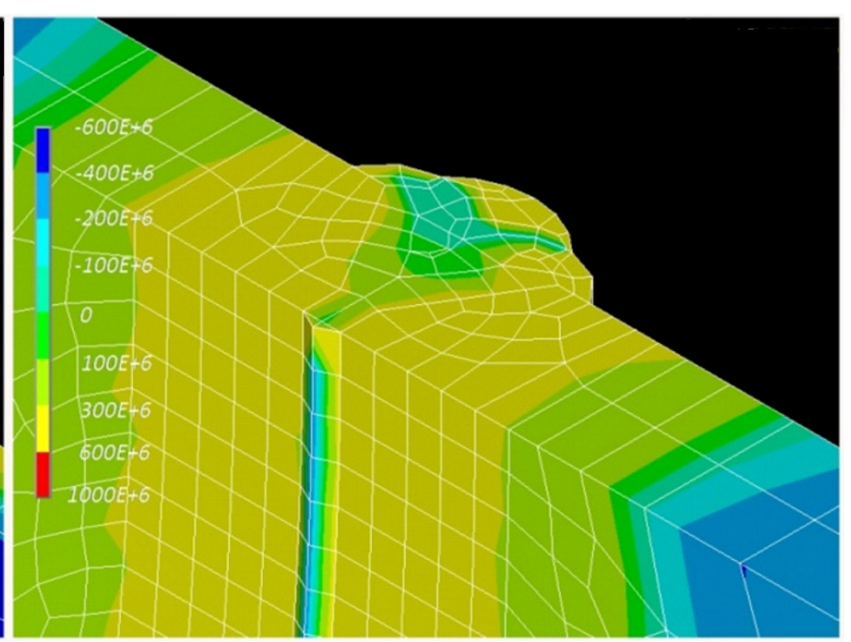

Figure 11a. Longitudinal Residual Stress Distribution of Model with Prime Martensite Only (left) and Model with Tempered Martensite (right). 


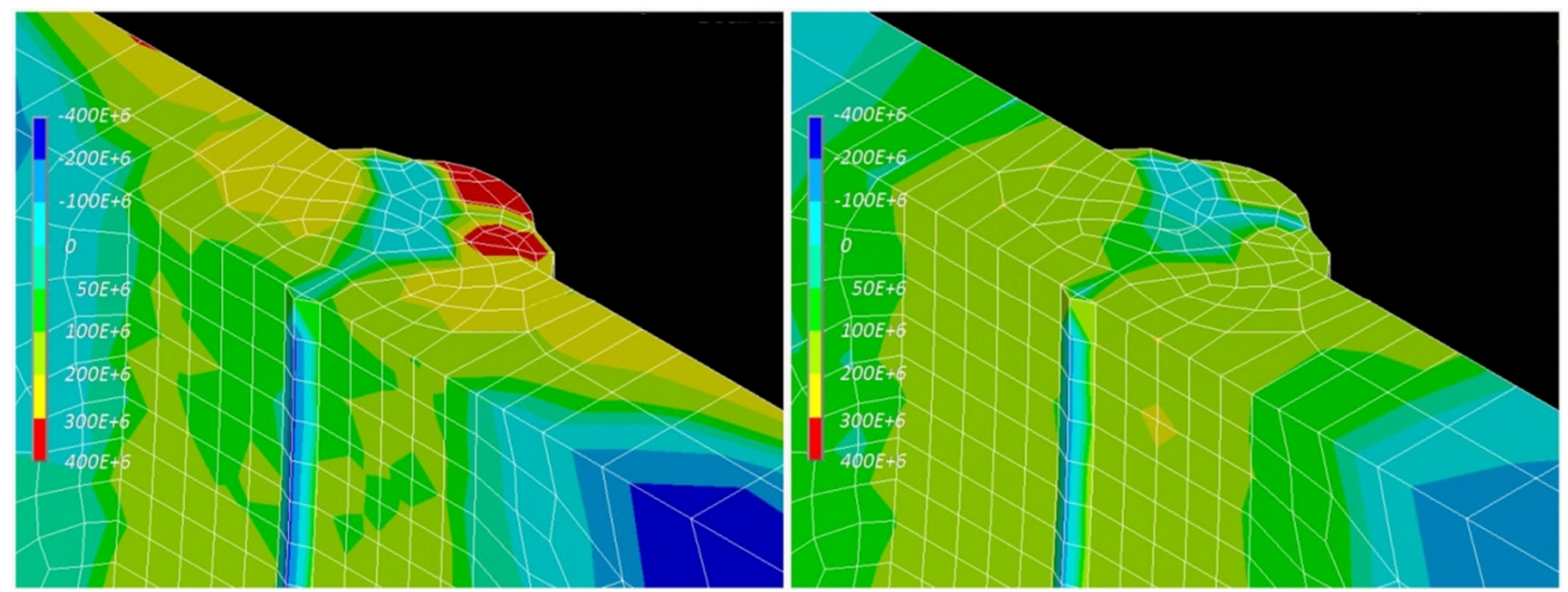

Figure 11b. Transverse Residual Stress Distribution of Model with Prime Martensite Only (left) and Model with Tempered Martensite (right).
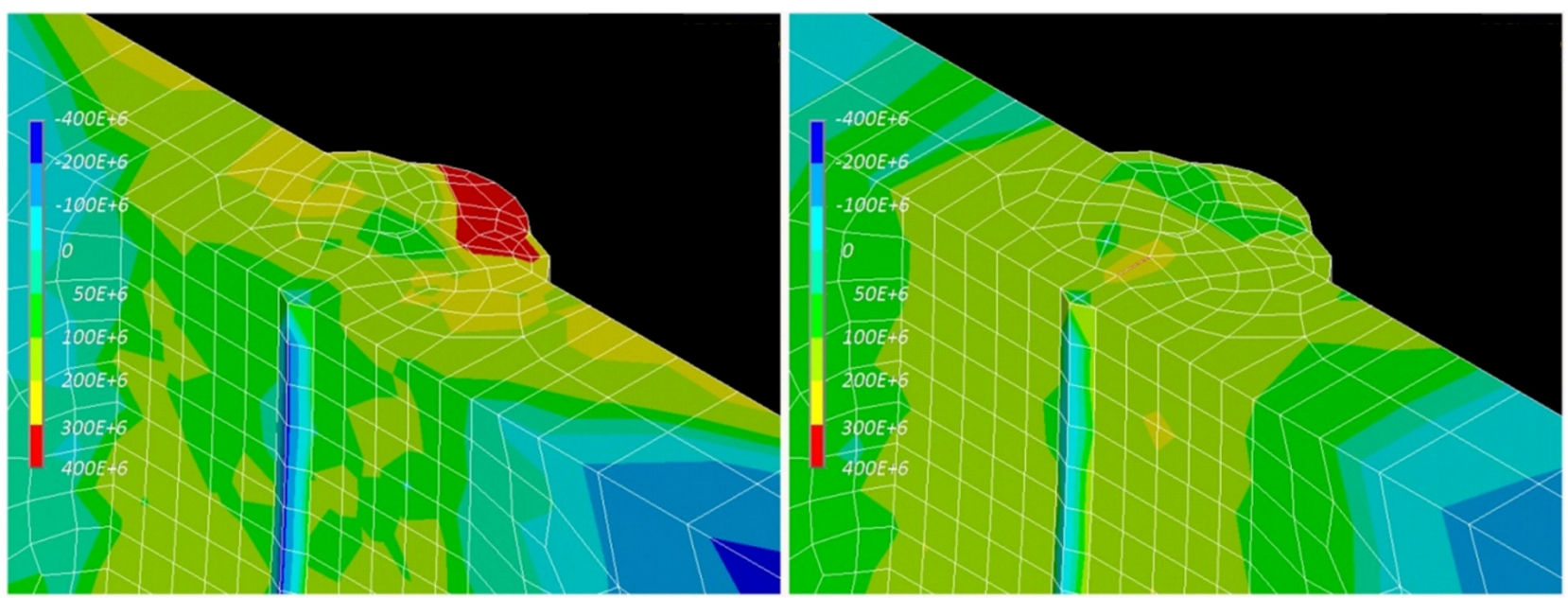

Figure 11c. Normal Residual Stress Distribution of Model with Prime Martensite Only (left) and Model with Tempered

\section{Martensite (right).}

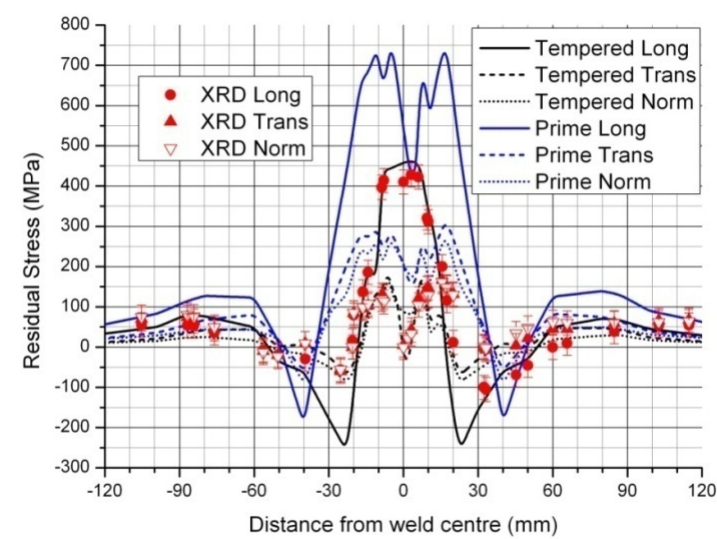

Figure 12. Residual Stresses at the 3 o'clock path

How the lower residual stress is produced by the bars with $1100 \mathrm{MPa}$ yield stress model can be understood by evaluating not only stress on the 3 bars model but also the strain. Stress and strain for the model with yield stress of the middle bar equalling $1000 \mathrm{MPa}$ are shown in Figure 16, whilst in Figure 17 for 1100 $\mathrm{MPa}$. The left shaded area shows the stress and strain condition when the mid bar is heated to $1100^{\circ} \mathrm{C}$ and the right part with white background shows the stress and strain state when the mid bar is cooled down to initial condition $\left(0^{\circ} \mathrm{C}\right)$. Indeed, when those bars are heated, the higher yield stress (model with $1100 \mathrm{MPa}$ for the mid bar) produces higher absolute stress on those bars (635.2 Mpa and -1270.5 MPa for side bars and mid bar respectively) and the model with lower yield stress (1000 MPa) produces lower absolute stresses (596.8 $\mathrm{MPa}$ for side bars and - 1193.6 MPa for middle bar). The higher absolute stress does not mean higher strains, especially plastic strain as can be seen by comparing Figs. 16 and 17. The total strains for lower yield stress model are $-1.697 \mathrm{~cm} / \mathrm{m}$ for the mid bar and $0.597 \mathrm{~cm} / \mathrm{m}$ for the side bars. The $-1.697 \mathrm{~cm} / \mathrm{m}$ total strain is comprised of $-1.197 \mathrm{~cm} / \mathrm{m}$ and $-0.503 \mathrm{~cm} / \mathrm{m}$ elastic and plastic strains respectively. For the $1100 \mathrm{MPa}$ model, the total strains are $0.635 \mathrm{~cm} / \mathrm{m}$ and $-1.613 \mathrm{~cm} / \mathrm{m}$ for side bars and mid bar respectively. This $-1.613 \mathrm{~cm} / \mathrm{m}$ is comprised of $-1.155 \mathrm{~cm} / \mathrm{m}$ and $-0.458 \mathrm{~cm} / \mathrm{m}$ elastic and plastic strains respectively. There is no plastic strain developed in the side bars.

The reason for the lower plastic strain developed in the model with a higher yield stress can be explored using stress-strain diagram in Figure 13. Higher yield stress in the mid bar exhibits higher stiffness mean, while the elongation depends on thermal expansion, which was not altered in the model developed in this article. For the equal temperature load $\left(1100^{\circ} \mathrm{C}\right)$ the thermal expansion in the mid bar will be the same. 

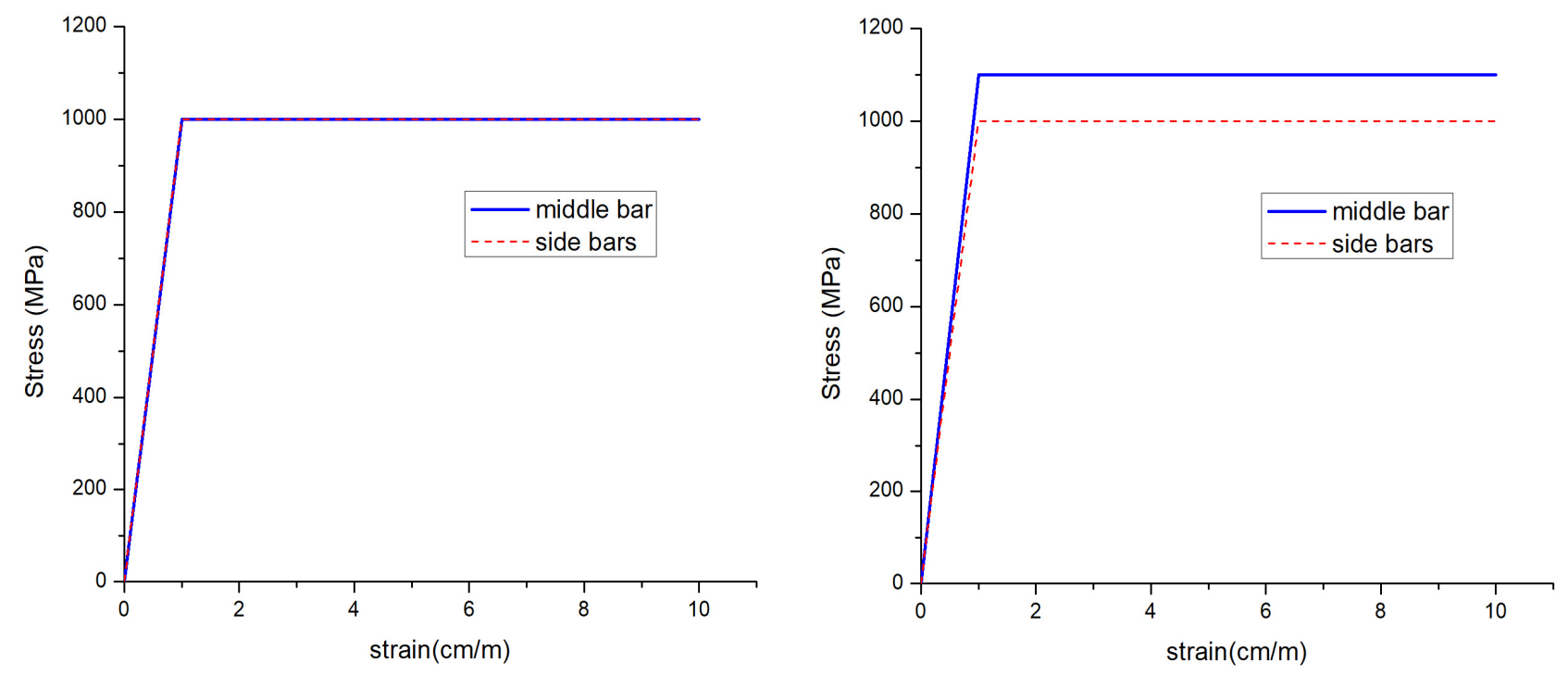

Figure 13. Stress Strain Diagram for 150MPa (left) and 160MPa (right) yield stresses

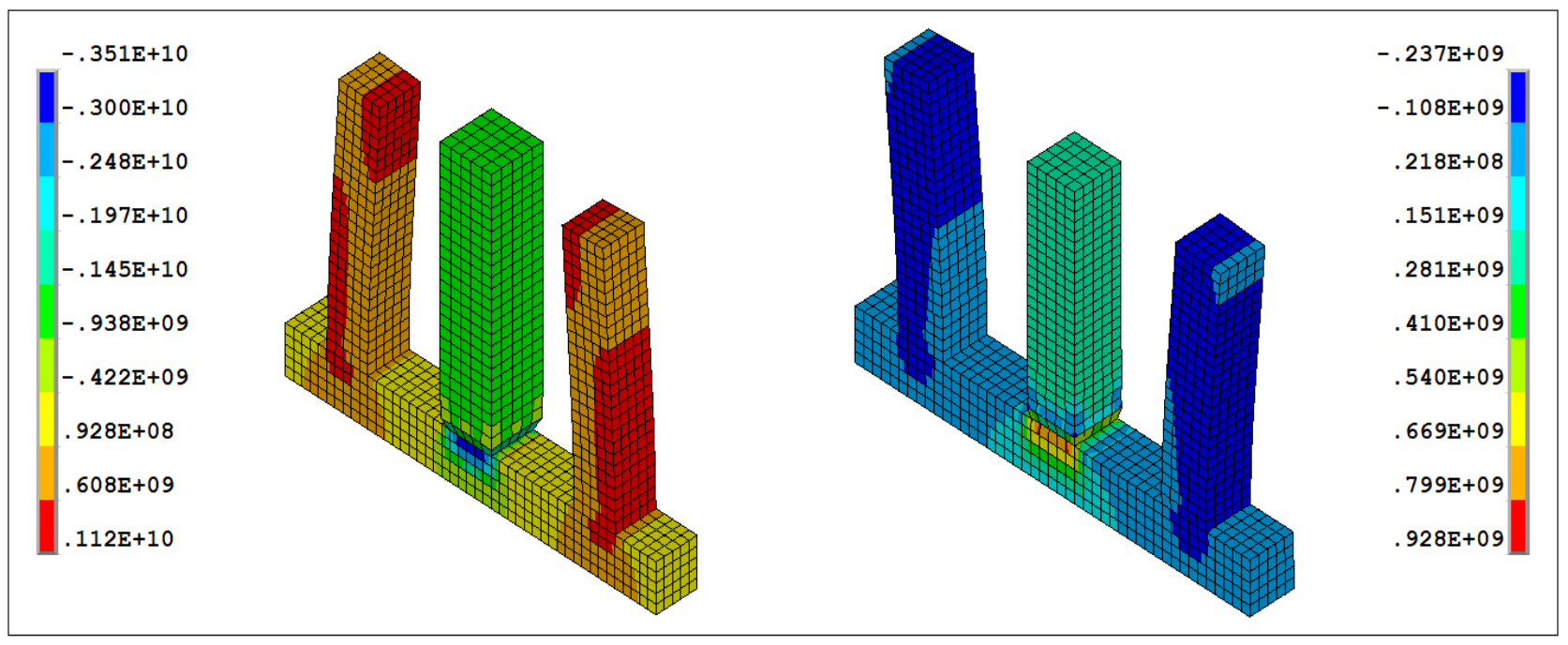

Figure 14. Stresses Distribution for a Model with Yield Stress of Middle Bar Equal to $1000 \mathrm{MPa}$ when The Middle Bar is Heated to $1100^{\circ} \mathrm{C}$ (Left) and when The Temperature Load is Omitted (right)

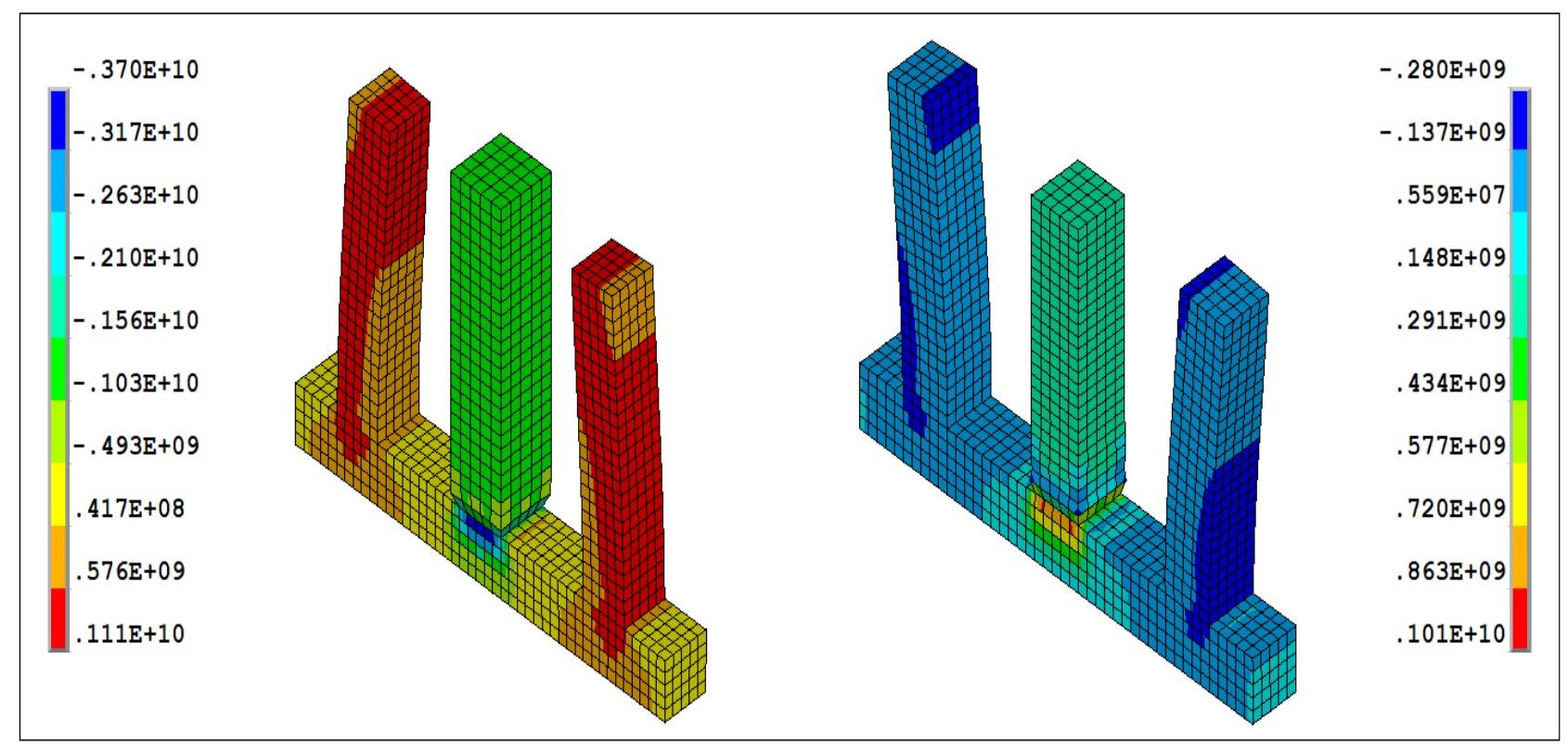

Figure 14. Stresses Distribution for a Model with Yield Stress of Middle Bar Equal to $1100 \mathrm{MPa}$ when The Middle Bar is Heated to $1100^{\circ} \mathrm{C}$ (Left) and when The Temperature Load is Omitted (right) 


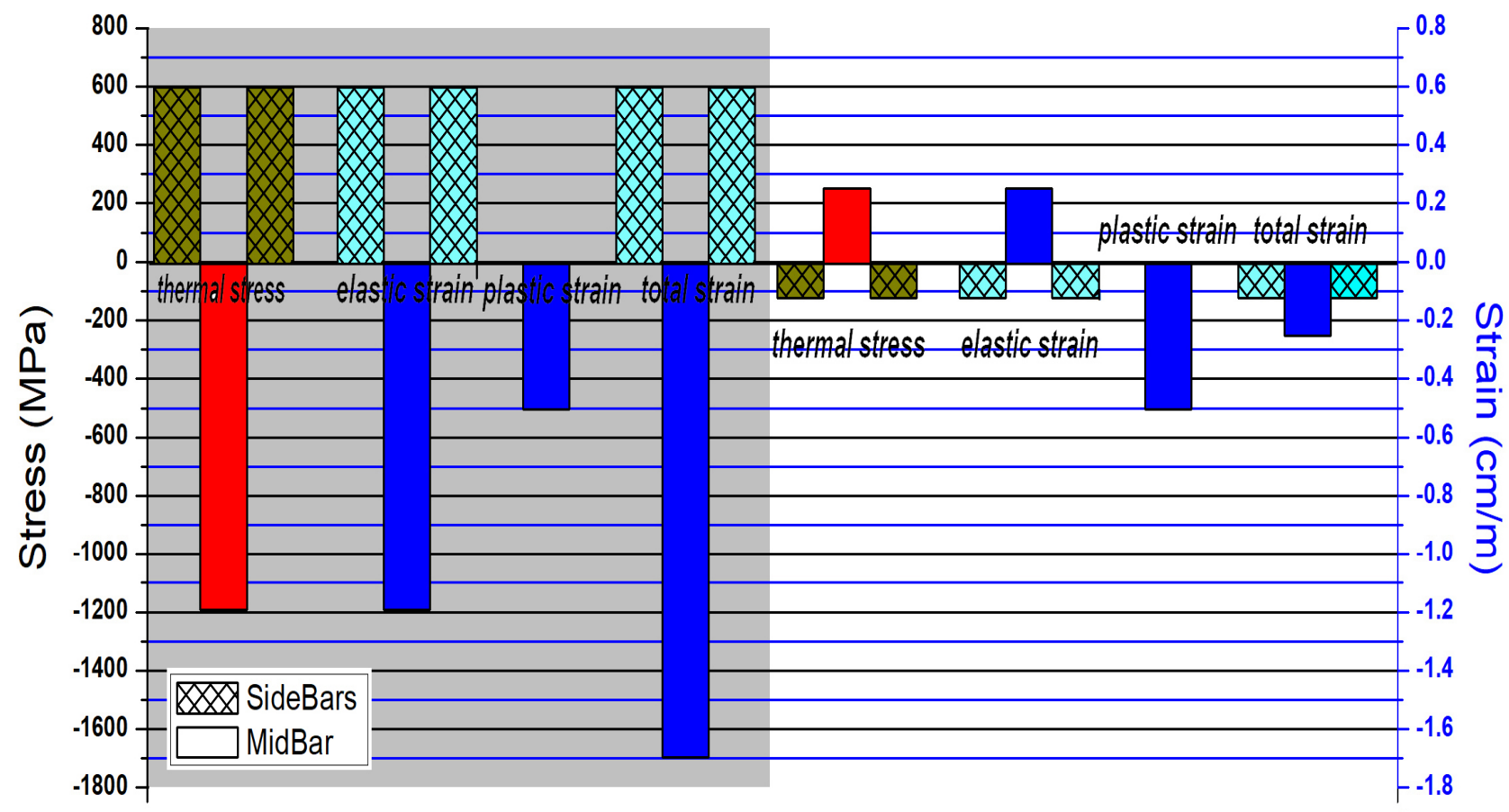

Figure 16. Stresses and Strain for Yield Stress of Middle Bar Equal to $1000 \mathrm{MPa}$ when Middle Bar Heated (left, with shaded area) and When Temperature Load is Omitted (Right)

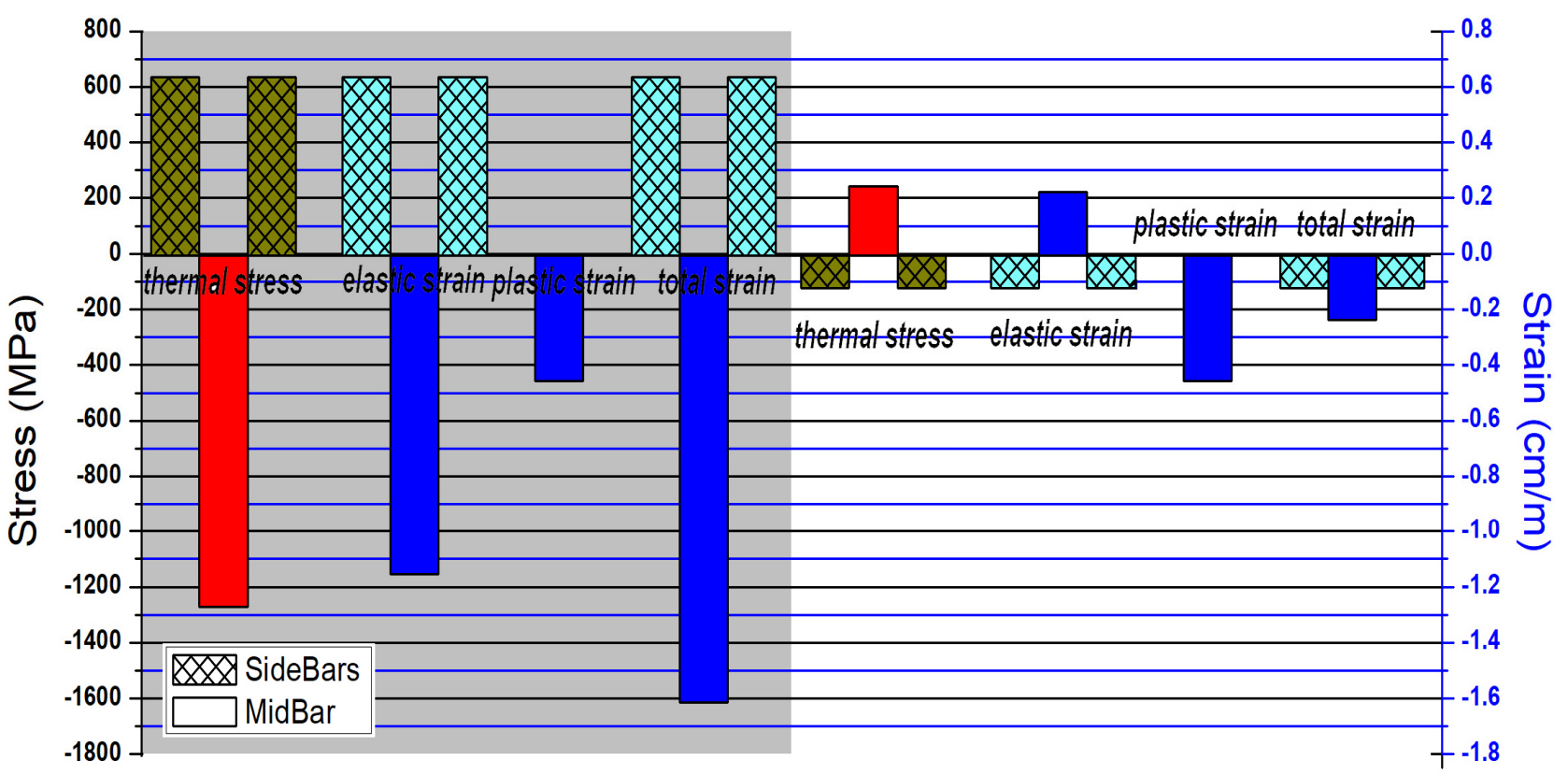

Figure 17. Stresses and Strain for Yield Stress of Middle Bar Equal to $1100 \mathrm{MPa}$ when Middle Bar Heated (left, with shaded area) and When Temperature Load is Omitted (Right)

Due to the high stiffness in the mid bar, the less absolute final total strain, while the mid bar is heated will be produced, whilst higher total strain was performed in the side bars. The lower absolute compressive strain finally embedded lower plastic strain in the mid bar $(-0.458 \mathrm{~cm} / \mathrm{m})$.

Another important aspect, as can be seen in Figs. 16 and 17 , is that this plastic strain which is developed when the mid bar is heated remains in mid bar when those bars are cooled down to room temperature, and the lower plastic strain $(-0.458 \mathrm{~cm} / \mathrm{m})$ for the high yield stress model $(1100 \mathrm{MPa})$ finally caused lower residual stress. This discussion may explain qualitatively why the model involving aged martensite in the multi-pass girth weld
FEM model caused lower residual stress in the area close to the weld line. And since the results considering aged martensite SSPT are closer to the experiment results, this model is considered to be correct.

Extrapolating simulations for the three bars model also have been done for yield stress of the mid bar equaling 1200, 1300, 1400 and $1500 \mathrm{MPa}$. The results are consistent that the higher yield stress does produce less residual stress, and these are: $250.17 \mathrm{MPa}, 243.36 \mathrm{MPa}$, $230.97 \mathrm{MPa}, 213.82 \mathrm{MPa}, 192.57 \mathrm{MPa}$ and $167.86 \mathrm{MPa}$ for yield stress of the middle bar equaling: $1000 \mathrm{MPa}$, $1100 \mathrm{MPa}, 1200 \mathrm{MPa}, 1300 \mathrm{MPa}, 1400 \mathrm{MPa}$ and 1500 $\mathrm{MPa}$ respectively. 


\section{CONCLUSIONS}

Based on the results of FEM model and analysis using simple three bars model, some conclusions can be obtained as below:

- The higher yield stress model for aged martensite produced a lower total strain when heated.

- The lower total strain due to the higher stiffness of aged martensite.

- The total strain comprised of elastic and plastic strain and lower total strain also means lower plastic strain.

- The plastic strain remains while the model is cooled down to room temperature.

- Due to geometrical misfit, the remaining plastic strain produces tensile stress in the weld line and compressive stress in the area apart from the weld line.

- Due to less plastic strain for the higher yield stress of aged martensite, the tensile stress involving aged martensite model yields lower developed stress.

Comparied to the measurement, the model involving aged martensite provides closer prediction and considered to be correct whilst the model with prime martensite only, shows overestimate of developed stress.

\section{REFERENCES}

[1] Dunn, B.D. and Bruno, G., "Surface and bulk residual stress in $\mathrm{Ti}_{6} \mathrm{Al}_{4} \mathrm{~V}$ welded aerospace tank", Journal of Pressure Vessel Technology, vol. 126, pp. 284-292, 2004.

[2] Kastratovic, G., Vidanovic, N., Grbovic, A., Rasuo, B.: Approximate determination of stress intensity factor for multiple surface cracks, FME Transactions, Vo. 46, No. 1, pp. 41-47, 2018.

[3] Petrasinovic, N., Petrasinovic, D., Rasuo, B., Milkovic, D.: Aircraft Duraluminium Wing Spar Fatique Testing, FME Transactions Vol. 45, pp. 531-536, 2017.

[4] Mochammad Noer Ilman and Triyono, "Fatigue crack growth behavior of friction stir welded aluminium alloy 2024-T3 under local preheating", International Journal of Material Science, vol.5, no.6, pp.791 - 800, 2010.

[5] O. Muransky, M.C. Smith, P.J. Bendeich, T.M. Holden, V. Luzin, R.V. Martins and L. Edwards, Comprehensive numerical analysis of a three-pass bead-in-slot weld and its critical validation using neutron and synchrotron diffraction residual stress measurements, International Journal of Solids and Structures, vol. 49, pp. 1045 - 1062, 2012.

[6] Djarot B. Darmadi, Analytic and finite element solution of temperature profiles in welding for transient state and quasi steady state using point heat source model, Int. Review of Mechanical Engineering, vol. 11, no.8, pp. $619-627,2017$.
[7] Djarot B. Darmadi, John Norrish and Anh KietTieu, Residual stress analysis of pipeline girth weld joints, Lambert Academic Publishing, Deutschland - Germany, 2015.

[8] L.E. Lindgren, Computational welding mechanics: thermomechanical and microstructural, Woodhead Publishing Limited, Cambridge, 2007.

[9] E. Armentani, R. Esposito and R. Sepe, The effect of thermal properties and weld efficiency on residual stresses in welding, Journal of Achievements in Materials and Manufacturing Engineering, vol. 20, issues 1-2, 2007.

[10] Hwa Teng Lee and Jia Lin Wu, Correlation between corrosion resistance properties and thermal cycles experienced by gas arc welding and laser beam welding alloy 690 butt weldments, Corrosion Science, vol. 51, pp. 733 - 743, 2009.

[11]Deng Dean, Hidekazu Murakawa \& Wei Liang, Numerical and experimental investigations on welding residual stress in multi-pass butt-welded austenitic stainless steel pipe, Computational Materials Science, vol. 42, pp. 234 - 244, 2008.

[12] Deng Dean and Hidekazu Murakawa, Prediction of welding residual stress in multi-pass butt-welded modified 9Cr-1Mo steel pipe considering phase transformation effects, Computational Materials Science, vol. 37, pp. 209-219, 2006.

[13] Lars-Erik Lindgren, Finite element modeling and simulation of welding part 1: increased complexity, Journal of Thermal Stresses, vol. 24, pp. 141-192, 2001.

[14] Djarot B. Darmadi, Evaluation of the effects of melting phenomenon on the residual stress formation in ferritic pipeline multi pass girth-weld joints, Int. J. Engineering Systems Modelling and Simulation, vol. 8, no. 3, pp. $205-217,2015$.

[15]R6 revision 4, Assessment of the integrity of structures containing defects, British Energy Generation Ltd., 2004.

[16] AF Mark, JA Francis, H Dai, M Turski, PR Hurrell, SK Bate, JR Kornmeier and PJ Withers, On the evolution of local material properties and residual stress in a three-pass SA508 steel weld, Acta Materialia, vol. 60, pp. 3268 - 3278, 2012.

[17]John Goldak, Aditya Chakravarti and Malcolm Bibby, A new finite element model for welding heat sources, Metallurgical Transactions B, vol. 15B, pp. $299-305,1984$.

[18] M.J. Painter and M.H. Davies, Numerical Modeling of The Gas Metal Arc Welding Process, Annual Report - CRC Project: 93.04; 1994.

[19] Djarot B. Darmadi, Validating the accuracy of heat source model via temperature histories and temperature field in bead-on-plate welding, International Journal of Engineering \& Technology, Vol.11, No.5, pp. 12 - 20, 2011.

[20] Djarot B. Darmadi, Anh Kiet Tieu and John Norrish, A validated thermal model of bead-on- 
plate welding, Heat and Mass Transfer, vol.48, pp. $1219-1230,2012$.

[21] M.R. Forouzan, A. Heidari and J. Golestaneh, FE simulation of submerged arc welding of API $5 \mathrm{~L}$ $X 70$ straight seam oil and gas pipes, Istiqlaal, vol.28, no.1, pp. 93 - 110, 2009.

[22] Kuzmikova, L., Callaghan, M., Larkin, N., Scott, R., De Jong, R., Li, H., "A study of the continous cooling behaviour and effect of preheat and interpass temperature on the HAZ of high strength quenched and tempered stell", IIW 2010 Annual Assembly (pp. 1 - 14), 2010.

[23] Dean Deng, Yangang Tong, Ninshu Ma and Hidekazu Murakawa, Prediction of the residual welding stress in $2.25 \mathrm{Cr}-1 \mathrm{Mo}$ steel by by taking into account the effect of solid-state phase transformations, Acta Metallurgica Sinica (English Letters) vol.26, no.3 pp. 333-339, 2013.

[24]D.P. Koistinen and R.E. Marburger, A general equation prescribing the extent of the austenitemartensite transformation in pure iron-carbon alloys and plain carbon steels, Acta Metallurgica, vol. 7, pp. $59-60,1959$.

[25] K.W. Andrews, Empirical formulae for the calculation of some transformation temperature, J. Iron Steel Res. Int. 203, pp. 721 - 727, 1960.

[26] Seok-Jae Lee and Young-Kook Lee, Latent heat of martensitic transformation in a medium-carbon low-alloy steel, Scripta Materialia, vol. 60, pp. 1016 - 1019, 2009.

[27] Ching-Hyung Lee, Computational modeling of the residual stress evolution due to solid-state phase transformation during welding, Modeling and Simulation in Materials Science and Engineering, vol. 16, pp. 1 - 16, 2008.

[28] R.I. Karlsson and B.L. Josefson, Three-dimensional finite element analysis of temperature and stresses in a single-pass butt-welded pipe, Transactions of the ASME, vol. 112, pp.. 76-84, 1990.

[29] Moudar H. Zgoul, Predicting the mechanical behaviou of steel frames exposed to elevated temperatures using artificial neural networks, WSEAS Transactions on System, Vol.9, Issue 8, pp. 895-904, 2010.

[30] N. Saunders, Z. Guo, A.P. Miodownik and J.P. Schille, Modeling the material properties and behavior of multicomponent alloys, $22^{\text {nd }}$ CAD-FEM users' meeting, International Congress on FEM Technology, 2004.

[31]Zhanli Guo, Nigel Saunders, Peter Miodownik and Jean-Philippe Schille, Modeling the strain-life relationship of commercial alloys, Proceedings of Eight International Conference on Creep and Fatigue at Elevated Temperature, San Antonio, Texas, 2007.

[32] Y. Desalos, Comportement Dilatometrique et Mecanique de l'Austenite Metastable d'un Acier A 533, IRSID Report \#95349401 in J.B. Leblond, J. Devaux and J.C. Devaux, Mathematical Modelling of Transformation Plasticity in Steels 1: Case of
Ideal-Plastic Phases, International Journal of Plasticity, Vol.5, pp. 551-572, 1989.

[33] S. Denis, A. Simon and G. Beck, Estimation of the Effect of Stress/Phase Transformation Interaction when Calculating Internal Stress During Martensite Quenching of Steel, Trans. Iron Steel Inst. Japan, 22, 505, 1982.

[34]RWK Honeycombe and HKDH Bhadeshia, Steels microstructure and properties, $2^{\text {nd }}$ edition, Gray Publishing, UK, 1995.

[35] Djarot B. Darmadi, Study of residual stress mechanism using three elasto-plastic bars model, Asian Transactions on Engineering (ATE), Volume 01 Issue 5, pp. 76-80, 2011.

\section{NOMENCLATURE}

$A_{w b} \quad$ Cross section area of formed weld bead $\left(\mathrm{mm}^{2}\right)$

$c_{p} \quad$ Specific heat $\left(\mathrm{J} / \mathrm{kg}^{\circ} \mathrm{C}\right)$

$\mathrm{fb} \quad$ Bainite fraction

fm Martensite fraction

$H_{M}^{\text {func }}$ Latent heat for martensite formation ( $\left.\mathrm{J} / \mathrm{mol}\right)$

$K \quad$ Desalos' constant $\left(\mathrm{MPa}^{-1}\right)$

$M_{s} \quad$ Temperature when martensite start to be formed $\left({ }^{\circ} \mathrm{C}\right)$

$\dot{q} \quad$ Heat rate $(\mathrm{J} / \mathrm{sec})$

$\dot{q}_{(x, y, \xi)}^{\prime \prime \prime}$ Volumetric heat load $\left(\frac{J}{\sec . m^{3}}\right)$

$r_{x}, r_{y}, r_{z} \quad$ Heat radius in $\mathrm{x}, \mathrm{y}$ and $\mathrm{z}$ senses $(\mathrm{mm})$

$t_{8 / 5} \quad$ Cooling rate (sec)

$v \quad$ Welding speed $(\mathrm{mm} / \mathrm{min} ; \mathrm{mm} / \mathrm{s})$

$w f s \quad$ Wire feed speed $(\mathrm{m} / \mathrm{min} ; \mathrm{mm} / \mathrm{s})$

$\alpha_{T} \quad$ Coefficient of thermal expansion $\left({ }^{\circ} \mathrm{C}\right)$

$\Delta \varepsilon^{\text {mar }} \quad$ Volumetric strain due to martensite formation

$\Delta \varepsilon^{\mathrm{TrP}} \quad$ Transformation Plasticity

$\Delta \varepsilon_{\mathrm{vol}} \quad$ Volumetric strain

$\lambda \quad$ Thermal conductivity $\left(\mathrm{W} / \mathrm{m}^{\circ} \mathrm{C}\right)$

$\xi \quad$ Longitudinal relative position to weld center (mm)

$\rho \quad$ Density $\left(\mathrm{kg} / \mathrm{m}^{3}\right)$

$\sigma \quad$ Normal stress (MPa)

\section{ИНТЕГРИСАЫЕ МОДЕЛА СТАРОГ МАРТЕНЗИТА ПРИЛИКОМ ПРЕДВИЪАЮА РЕЗИДУАЛНОГ НАПРЕЗАҢА КОД ОБИМНОГ ЗАВАРИВАњА СПОЈЕВА У ОБОДУ ОД ФЕРИТНОГ ЧЕЛИКА}

\section{Ђ.Б. Дармади}

Предвиђање резидуалног напрезања извршено је помоћу модела заваривања у вишеструком ободу применом процедуре коначних елемената. Обављена је ТММ анализа и предвиђено резидуално напрезање је упоређено са експерименталним резултатима. У циљу утврђивања улоге старог мартензита код резидуалног напрезања обављена је симулација и анализа два модела, са и без старог мартензита 
(само са примарним мартензитом). Поређење експерименталних резултата је показало да је модел са старим мартензитом ближи резултатима пред- виђања у односу на модел без старог мартензита који је у процени резидуалног напрезања био далеко изнад реалне вредности. 